\title{
Promises of stem cell therapy for retinal degenerative diseases
}

\author{
Ian Yat-Hin Wong • Ming-Wai Poon • \\ Rosita Tsz-Wai Pang • Qizhou Lian • David Wong
}

Received: 4 April 2011 /Revised: 19 May 2011 / Accepted: 28 July 2011 / Published online: 25 August 2011

(C) The Author(s) 2011. This article is published with open access at Springerlink.com

\begin{abstract}
With the development of stem cell technology, stem cell-based therapy for retinal degeneration has been proposed to restore the visual function. Many animal studies and some clinical trials have shown encouraging results of stem cell-based therapy in retinal degenerative diseases. While stem cell-based therapy is a promising strategy to replace damaged retinal cells and ultimately cure retinal degeneration, there are several important challenges which need to be overcome before stem cell technology can be applied widely in clinical settings. In this review, different types of donor cell origins used in retinal treatments, potential target cell types for therapy, methods of stem cell delivery to the eye, assessments of potential risks in stem cell therapy, as well as future developments of retinal stem cells therapy, will be discussed.
\end{abstract}

Keywords Retinal degenerative diseases - Stem cell therapy · Donor cells · Target cell types · Method of cell delivery $\cdot$ Potential risks $\cdot$ Clinical applications

The authors have full control of all primary data, and agree to allow Graefe's Archive for Clinical and Experimental Ophthalmology to review their data upon request.

I. Y.-H. Wong $\cdot$ Q. Lian $(\bowtie) \cdot$ D. Wong

Department of Medicine and Eye Institute,

Li Ka Shing Faculty of Medicine, University of Hong Kong,

Pokfulam, Hong Kong SAR, PRC

e-mail: qzlian@hkucc.hku.hk

M.-W. Poon • R. T.-W. Pang • Q. Lian

Cardiology Division, Department of Medicine,

University of Hong Kong,

Pokfulam, Hong Kong SAR, PRC

I. Y.-H. Wong • M.-W. Poon • Q. Lian • D. Wong

Research Centre of Heart, Brain, Hormone, and Healthy Aging,

Li Ka Shing Faculty of Medicine, University of Hong Kong,

Pokfulam, Hong Kong SAR, PRC

\section{Introduction}

Retinal degeneration culminating in retinal cell loss is a major cause of permanent blindness in the world, leading to the loss of human resources and imposing a great financial burden of health care. Retinal degeneration can be found in the entire age spectrum. Epidemiologic studies have shown that retinitis pigmentosa (RP) affects predominantly the pediatric and young adult population [1], while diabetic retinopathy (DR) affects middle-aged adults [2], and agerelated macular degeneration (AMD) affects the elderly.

Current therapeutic strategies for retinal degenerative diseases include pharmacological treatment, surgical intervention, and cell replacement. Pharmacological treatment is the commonest approach, but it is frequently ineffective for degenerative diseases such as RP. Surgical intervention such as autologous translocation of retinal pigment epithelium (RPE) have been tried for the treatment of neovascular AMD [3, 4], but outcomes are variable, and such surgical intervention is technically difficult. More importantly, this surgery is unable to regenerate damaged retinal. Poor renewability of retinal neurons has further limited the efficacies of the above therapies.

Recently, stem cell-based therapy for retinal degeneration has been proposed with the development of stem cell technology [5]. Stem cell-based therapy has been tested in animal models for several retinal degenerative diseases [6]. In 2010, the Food and Drug Administration (FDA) approved a phase I/II clinical trial using human embryonic stem cell (hESC)-derived RPE cells for the treatment of dry AMD. Transplantation of functional retinal cells or stem cells aims to restore vision by repopulating the damaged retina via rescuing retinal neurons from further degeneration. Although this is a milestone in clinical therapeutics, ethical controversies and risk of immune rejection have limited hESC-based 
therapy in clinics. Despite the possibility of curing the degenerative process [7], there are still many obstacles before stem cell technology can be applied in daily practice. In this review, different types of donor cell origins used in retinal treatments, potential target cell types for therapy, method of delivery, assessments of potential risks in stem cell therapy, and also future developments will be discussed.

\section{Donor cell origins}

The success of stem cell therapy is highly dependent on the ability of donor cells to migrate into the desired location, to survive after transplantation, and to differentiate into retinal cells to restore retinal function. Recent researches have shown that several cell populations may be considered as potential sources. These include fetal stem cells, pluripotent stem cells (embryonic stem cells and induced pluripotent stem cells) and adult stem cells.

\section{Fetal stem cells}

Fetal stem cells are fetal retinal cells, at the exact developmental time when these cells are born and about to form intrinsic connections. Previous studies have shown that, before the formation of synaptic connections, retinal ganglion cells can regenerate after axotomy and navigate through the optic chiasm [8]. It has been proposed that immature photoreceptors might also have the capacity to reconnect themselves to the central neural system (CNS) after transplantation. Fetal retinal progenitor cells (RPCs) derived from a range of mammalian species, including rats $[9,10]$, pigs [11], and humans, [12] have been tried. It has been shown that rodent fetal RPCs are able to propagate extensively, expressing photoreceptor markers. Transplantation of fetal RPCs resulting in the survival and differentiation of the grafted tissue has been proven to be associated with behavioral benefits in retinal dystrophic recipients [13, 14]. Fetal neurons appear to show higher survival capacities than adult neurons [15]. For human fetal-derived retinal cells, Young [12] isolated proliferating human retinal progenitor cells (hRPCs) from 10th to 13rd week of gestation, and demonstrated that they could be expanded in tissue culture. However, their proliferating capacity was weak, and population declined quickly. Recently, Aftab et al. [15] have shown that donor tissues taken from 16th to 18th week of gestation give the longest in-vitro survival time, and the highest number of cells. After transplantation, these cells were integrated into the recipient retina, and differentiated into rhodopsin positive cells. This result supported the potential of hRPC transplantation for degenerative diseases. Nevertheless, ethical issues still exist, and the supply of such cells is still limited.
Embryonic stem cells and induced pluripotent stem cells

An alternative is to use embryonic stem cells and induced pluripotent stem cells (ESC/iPSC). ESCs/iPSCs have a great potential to differentiate into any of the 200 or more adult cell types. Hence ESC/iPSC provides potentially unlimited cell sources for the generation of retinal cells. In-vitro differentiation of ESC/iPSC into functional retinal cell types is achievable by defined step-wise protocols [1619]. ESCs could be induced to differentiate into eye-like structures that contained cells with properties of crystalline lens, neural retina, and RPE [20]. Further studies have indicated that cells from these eye-like structures could be further differentiated into RGCs when transplanted into the vitreous of an injured adult mouse retina [21]. Recently, the success of defined differentiation of human ESC-derived RPE cells (hESC-RPE) has been reported [22]. Following transplantation in animal models, restoration of vision had been reported and no tumor formation was seen $[19,23]$. In 2010, the FDA approved the first clinical trial using hESCRPE for the treatment of dry AMD and Stardgart's disease (STGD) in humans. Hopefully results will be available in the near future. The main advantage over adult-derived RPE cell lines is the ability to produce differentiated RPE cells in vitro, which is less immunogenic.

Transplantation of hESC-derived RPE cells has proved to be a milestone in clinical therapeutics. Nevertheless, its use is still limited by ethical controversies and the risk of rejection. Induced pluripotent stem cells (iPSC) offer an alternative cellular source for patient-specific treatment without the risk of rejection and ethical problems [24, 25]. Nonetheless, clinical application of iPSCs is limited by the risks of proviral integrations and potential insertional mutagenesis during delivery of reprogrammed factors using virus. To overcome these issues, efforts toward the generation of "clinical grade" iPSC have been proposed. Recently, the reprogramming technologies in iPSC generation have been rapidly improved by the use of chemicals, plasmids, synthesized mRNAs, and direct protein delivery [26-29]. In the future, transplantation of photoreceptors with or without RPE cells derived from these sources provides enormous potential for treating retinal degenerations. Personalized treatment strategy is potentially possible with the use of iPSCs, assuming that the risks associated are minimized.

\section{Adult stem cells}

It is known that lower vertebrates, such as teleosts or amphibians, have the ability to regenerate new retinal neurons throughout life, from a region called the ciliary marginal zone (CMZ) [30, 31]. It was also thought that the adult mammalian ciliary body (CB) might harbor retinal stem cell. In 2000, two independent groups discovered that the 
ciliary epithelium (CE) of the murine eye contains multipotent retinal stem cells $[32,33]$. It was shown that single pigmented cells from the $\mathrm{CE}$ of mouse retina could clonally proliferate in vitro and form sphere colonies. These cells have the ability to be induced into retinal-specific cell types, including rod photoreceptors, bipolar neurons, and Müller glia.

Similar multipotent retinal stem cells were later identified in other mammalian species, including pigs and humans [34, 35]. These cells were proliferative, but to a lesser extent than fetal or ESC-derived retinal stem cells. When these cells were transplanted into adult mice, new photoreceptors were induced [35].

Another source of retinal stem cells was later discovered within the iris epithelium by Haruta and colleagues in 2001 . The iris epithelium might harbor discrete heterogeneous populations of cells endowed with innate neural stem cell properties, including the ability to differentiate into retinal specific neurons $[36,37]$.

After the discovery of adult retina-specific stem cells, a number of laboratories have sought to expand numbers of such adult retina-specific stem cells and optimize sub-retinal differentiation. However, there are several obstacles to the use of such cells. Firstly, the percentage of actively proliferating cells in the CE is very few $(<2 \%)$ [38]. Secondly, self-renewal and proliferation rates would decrease gradually with subsequent passages $[35,38]$. Thirdly, there may be a risk of tumour formation, as reported by Djojosubroto [39] in a recent study. Furthermore, Gualdoni [40] found that the expansion of CE-derived cells quickly led to the loss of retinal progenitor cell markers and hence reduced the potential of photoreceptor differentiation. Further investigations are needed to delineate the intrinsic mechanisms governing adult stem cell self-renewal and differentiation, as well as genetic stability.

Other adult stem cells have also been reported to be capable of inducing retinal regeneration. These include neural progenitor cells (NPC) [41, 42], hematopoietic stem cells (hSC) [43], and mescenchymal stem cells (MSC) [44]. NPCs have been shown to promote the recovery from retinal injury and to express retinal phenotypic neurochemical markers [45]. However, reports have shown that NPC lacks the ability to differentiate into mature retinal neurons [46]. Furthermore, the shortage of adult NPC sources has further limited its application.

Autologous transplantation using hSC or MSCs has the advantage of reducing the risk of rejection and avoiding ethical controversies. Using retinal ischemia-reperfusion models, anatomical integration has been reported by intravitreal injection of hSCs [43, 47] and MSCs [48]. Animal studies have demonstrated that MSCs is capable of integrating into the ganglion cells and nerve fiber layers. Due to the fact that MSC derived from an elderly donor has limited functions, MSC derived from human embryonic stem cells or iPSCs serves as an alternative source $[49,50]$.

Functional retinal differentiation from hSCs or MSCs is still highly debatable. More evidence has suggested that improvements with the use of adult hSCs or MSCs may actually be attributed to the secreted neurotrophic factors and anti-inflammatory cytokines in situ, instead of direct functional retinal differentiation [44, 51].

Retina-specific cell types can be derived from various cell sources. Different cell sources and important growth factors and chemical modulators used to promote retinal cell differentiation are summarized in Table 1.

Adult bone marrow stem cells

Cells of bone marrow origin have also been used for retinal regeneration. Bone marrow contains subsets of nonhaematopoietic lineages, which are capable of multilineage differentiation into cells of non-haematopoietic capabilities. These include mesenchymal, endothelial, and very small embryonic/epiblast-like stem cells (VSEL). These cells proliferate and act in response to tissue injury or damage. Although most of these cells are organrestricted, some appear to retain multipotential capacities [52]. In a mouse model, Li [53] showed that adult bone marrow-derived stem cells (BMSC) could be induced into RPE lineage in vitro. When infused back in vivo, these BMSC-derived RPE cells can home onto the focal areas of RPE damage, and form a monolayer on Bruch's membrane.

\section{Potential target cell types for therapy}

Retinal pigmented epithelial cells (RPE)

Retinal pigment epithelium is essential for the maintenance of neural retinal function. There is evidence suggesting that retinal degeneration can be treated with subretinal injections of RPE cells. Transplantation of RPE was first reported in the late 1980s [54, 55], on dystrophic Royal College of Surgeons (RCS) rats. These rats have defective RPE cells, which eventually lead to photoreceptor cell death. Since then, significant progress has been made regarding autologous RPE transplantation. Recent advances in stem cell culture and differentiation techniques have made possible the generation of RPE cells from pluripotent stem cells. It was shown that using RPE cells derived from hESC lines effectively improves photoreceptor survival in RPEdefective RCS rats [56]. These RPE cells also prevented the onset of secondary degenerative events [57].

Since the first case report of human homologous and autologous RPE transplantation for the treatment of exudative AMD in 1991 [58], more than 30 homologous 
Table 1 Different cell sources and important growth factors/ chemical modulators used to promote retinal cell differentiation

\begin{tabular}{|c|c|c|c|}
\hline Cell/ tissue type & Growth factor/chemical modulator & Primary differentiation & Reference \\
\hline \multicolumn{4}{|l|}{ Fetal stem cells } \\
\hline Retinal progenitors (r) & EGF, FGF2, heparine & Photoreceptors & {$[9,10]$} \\
\hline Neural retina progenitor cells (r) & $\begin{array}{l}\text { FGF2 and NT3 (removal } \\
\text { from medium) }\end{array}$ & $\begin{array}{l}\text { Glial cells, neurons expressing rhodopsin, } \\
\text { calbindin, calretinin }\end{array}$ & [82] \\
\hline Progenitor cells neural retina (porcine) & $\mathrm{CNTF}$ and no EGF and bFGF & Photoreceptors & [11] \\
\hline Human retinal progenitor cells & NT3, FGF2 & Retinal cell (cell culture) & {$[12]$} \\
\hline Retinal progenitor cells (m) & EGF & Mature neurons, rhodopsin, or cone opsin & [13] \\
\hline Photoreceptor precursors (m) & $\begin{array}{l}\text { Transplantation of cells into } \\
\text { immature retina }\end{array}$ & Rod photoreceptors, synaptic connections & {$[14]$} \\
\hline Retinal progenitor cells (h) & $\begin{array}{l}\text { Transplantation of cells into } 16 \text { to } \\
18 \text { weeks G.A. B6 mice }\end{array}$ & Photoreceptors & {$[15]$} \\
\hline \multicolumn{4}{|l|}{ ESC and iPSC } \\
\hline ESCs $(h)$ & $\begin{array}{l}\text { Stepwise treatment with } \\
\text { defined factors }\end{array}$ & Photoreceptors and RPE & {$[16]$} \\
\hline ESCs and iPSCs (h) & $\begin{array}{l}\text { Casein kinase I inhibitor, ALK4 } \\
\text { inhibitor, the pho- kinase inhibitor }\end{array}$ & $\begin{array}{l}\text { Retinal progenitors, retinal pigment epithelium } \\
\text { cells and photoreceptors }\end{array}$ & {$[17]$} \\
\hline iPSCs (h) & No bFGF & RPE (cell culture) & {$[83,84,85]$} \\
\hline $\operatorname{ESCs}(\mathrm{h})$ & $\mathrm{KOM}$, nicotinamide, $\mathrm{TGF}$ & RPE (cell culture) & {$[86,87]$} \\
\hline $\mathrm{ESCs}(\mathrm{m})$ & bFGF, Dex, cholera toxin & $\begin{array}{l}\text { A structure consisting of lens, neural retina, and } \\
\text { pigmented retina(tissue culture)(cell culture) }\end{array}$ & [20] \\
\hline $\operatorname{ESCs}(\mathrm{m})$ & NMDA-treated eyes & Eye-like structure & [21] \\
\hline $\operatorname{ESCs}(\mathrm{h})$ & bFGF, xeno-free & RPE (tissue culture) & [88] \\
\hline $\operatorname{ESCs}(\mathrm{m})$ & No LIF, retinoic acid & Neural progenitors, retinal cells & [23] \\
\hline iPSCs(h) & $\begin{array}{l}\text { KOS, zfbFGF, taurine, triiodo } \\
\text { thyronin, hydrocortisone }\end{array}$ & RPE & {$[25]$} \\
\hline \multicolumn{4}{|l|}{ Adult stem cells } \\
\hline $\begin{array}{l}\text { Dissociated cells from the RPE } \\
\text { and the NR }(\mathrm{m})\end{array}$ & EGF, FGF2 & $\begin{array}{l}\text { Rod photoreceptors, bipolar neurons, } \\
\text { and Müller glia }\end{array}$ & {$[32]$} \\
\hline $\begin{array}{l}\text { Adult iris, pars plana, and ciliary } \\
\text { body progenitor cells }\end{array}$ & FGF2 & Neurons and glia & {$[34]$} \\
\hline $\begin{array}{l}\text { Pars plicata and pars plana of the retinal } \\
\text { ciliary margin progenitor cells(h) }\end{array}$ & FGF2, heparin, EGF & Photoreceptors & {$[35]$} \\
\hline $\begin{array}{l}\text { Multipotent cells within the IPE of } \\
\text { postnatal and adult }(r)\end{array}$ & bFGF & $\begin{array}{l}\text { Neural retinal cells, RPE, } \\
\text { photoreceptors (cell culture) }\end{array}$ & {$[36]$} \\
\hline $\begin{array}{l}\text { Adult hippocampus-derived neural } \\
\text { progenitor cells }(\mathrm{r})\end{array}$ & $\mathrm{N} 2, \mathrm{bFGF}$ & Retinal neurons & {$[41]$} \\
\hline Hematopoietic progenitor cells (m) & SDF-1 $\alpha$ & RPE & [43] \\
\hline Hippocampus-derived neural stem cells (r) & $\mathrm{N} 2, \mathrm{bFGF}$ & Neurons and glia & [46] \\
\hline Adult CD90+MSC (r) & activin $\mathrm{A}$, taurine, and $\mathrm{EGF}$ & Rhodopsin, opsin, recoverin & [48] \\
\hline UCB-MSCs (h) & TGF $\beta$, CNTF, NT-3, BDNF & RGCs (superior colliculus) & [89] \\
\hline Ciliary body (m) & bFGF, GDNF & Photoreceptor, bipolar cell & {$[90]$} \\
\hline $\operatorname{Iris}(\mathrm{r})$ & FGF2 & Rod photoreceptor & [91] \\
\hline
\end{tabular}

Key:

$\mathrm{h}$ - human

$\mathrm{m}$ - mouse

ESC - embryonic stem cells

iPSC — induced pluripotent stem cells

$\mathrm{NR}$ - neural retina

UCB - umbilical cord blood

MSC - mesenchymal stem cells

IPE — iris pigmented epithelium

$\mathrm{RPE}$ - retinal pigment epithelium

$\mathrm{RGC}$ - retinal ganglion cell 
and 230 autologous RPE grafts have been performed [59]. The technique of harvesting RPE-choroid patch graft from the periphery, followed by insertion under the macula through retinotomy, was first described by van Meurs in 2003 [60]. It is now the most popular method of choice for RPE transplantation. Recent reports have shown that autologous RPE-choroid graft is able to produce sustainable longterm improvement in terms of vision and microperimetry performance, for neovascular age-related macular degeneration [61]. Other than autologous grafts, allogeneic and cultured HLA-typed cadaveric RPE cells have also been proposed for clinical application [62].

\section{Photoreceptor}

The mammalian retina contains highly specialized photoreceptors that are capable of capturing photons and transducing them into electrical signals. Replacing photoreceptors is much more challenging than RPE cells because the connection between photoreceptors and neurons are lost, and also because of the potential scarring response elicited. In 1999, Kwan [63] successfully transplanted photoreceptors in a mouse model of retinal degeneration. Outer segment reconstitution was observed in the recipient mice, and the mice were able to perform a simple light-dark discrimination test. Improvements in visual function have also been reported following transplantation of multipotent retinal progenitor cells derived from green fluorescent protein (GFP)-expressing mice [13].

Other transplantation strategies include grafting of retinal sheets, with or without attached RPE, into eyes of various rodent models of retinal degeneration [64]. Most recently, a few reports have demonstrated the ability of human neonatal photoreceptor precursors to differentiate and integrate into the outer nuclear layer (ONL) in both the intact and the degenerating retina of mature mice [14, 65]. Evidences has shown that photoreceptors and embryonic retinal tissue, when transplanted into the subretinal space, can form new synapses with existing host neurons. However, at the moment, photoreceptor transplants remain in the stage of laboratory science. The development of a combined tissue-engineered scaffold targeting both RPE and photoreceptors may be a promising direction for future research. Recent studies on stem cell therapy in retinal diseases are summarized in Table 2.

\section{Methods of delivering stem cells}

Currently the two most popular methods of delivering stem and progenitor cells into the eye are the intravitreal route and the subretinal route. The intravitreal route delivers stem cells into the eye through an injection using a small-gauge needle (e.g., 30-gauge). This method is technically easier and less invasive. However, the cells have to migrate through the vitreous and inner retina to the outer retina. There are also no means of directing the cells toward the target treatment area. Some studies have demonstrated that, compared to subretinal injections, intravitreal injection of stem cells resulted in a higher survival rate and fewer invasions by immune cells [66, 67]. On the other hand, the subretinal delivery method is more technically demanding and more invasive. The cells are injected through the sclera and choroid, into the subretinal space, using a small-gauge needle. This method has the advantage of directing the cells towards targeted treatment areas. Some reports have shown that the subretinal route has resulted in better localization and differentiation of neural stem cells than the intravitreal route $[68,69]$. Recently, there is a report of delivering stem cells subretinally on a biodegradable polymer composite graft [70]. Tomita and associates have shown a 10-fold increase in the number of surviving cells with this technique when compared to the conventional technique. In general, both routes have proved efficacious and are being routinely employed by stem cell researchers.

\section{Potential obstacles and risks}

\section{Limitation of integration}

Integration of graft cells into host tissue is another major obstacle at the moment. Wang et al. [55] reported their results following injection of both RPE cells of cell line ARPE-19 and human Schwann cells (hSC). By 15 weeks after injection, only hSC was able to form a monolayer of cells at the level of RPE. Despite displaying diploid properties and expressing RPE-specific markers, ARPE-19 cells did not show properties of RPE cells when injected and failed to form a monolayer of cells [71]. Klimanskaya [72] also observed that ESC-derived RPE cells remained aggregated when grafted, and failed to form a monolayer over the defective RPE in the subretinal space.

The reason for the behavior of grafted cells in failing subretinal expansion may be due to the high levels of retinoids within the host RPE cells. Retinoid is known to be able to inhibit cellular division, which may have also inhibited the transplanted cells from integrating. To overcome this limited integration, transplanting RPE cell sheets instead of RPE cells has been proposed [73]. Concomitant pharmacological modulations of the extracellular matrix may also improve host integration [74]. As transplantation techniques advance, future studies may incorporate more adjuncts to improve the integration of grafted cells into the host.

Inflammation and immunoreaction

Inflammation is activated in retinal degeneration primarily by microglia and macrophages $[75,76]$. When a lesion is 
Table 2 Recent studies on stem cell therapy in retinal diseases

\begin{tabular}{|c|c|c|c|c|}
\hline Retinal diseases & Donor cell type (species) & Target (species) & Outcomes & Ref. \\
\hline \multirow{5}{*}{$\begin{array}{l}\text { Retinal } \\
\text { degeneration }\end{array}$} & $\mathrm{h} / \mathrm{mBM}-\mathrm{SCs}$ & Retinal cells (m) & Retinal degeneration rescued & [92] \\
\hline & hBM- somatic cells & Photoreceptors (r) & $\begin{array}{l}\text { These cells were differentiated into 3-6 layers } \\
\text { of photoreceptors }\end{array}$ & [93] \\
\hline & rBM- MSCs & Retinal cells (r) & $\begin{array}{l}\text { Grafted cells expressed a rod photoreceptor } \\
\text { and bipolar and amacrine cell markers }\end{array}$ & [94] \\
\hline & Primate ESCs & Primate retinal cells & $\begin{array}{l}\text { Co- culturing ESCs with ESC-derived RPE } \\
\text { cells is efficient for inducing photoreceptors }\end{array}$ & [95] \\
\hline & mESCs & Retinal cells (m) & ESCs differentiates to various retinal cell types & [96] \\
\hline Neural retina repair & $\begin{array}{l}\text { mPostmitotic rod } \\
\text { photoreceptor } \\
\text { precursor cells }\end{array}$ & Rod photoreceptors (m) & $\begin{array}{l}\text { Photoreceptors were present up to } 12 \text { months } \\
\text { post-transplantation }\end{array}$ & [97] \\
\hline Retinitis pigmentosa & mBM-MSCs & Microglia (m) & $\begin{array}{l}\text { These microglia plays a protective role in } \\
\text { retinitis pigmentosa }\end{array}$ & [98] \\
\hline $\begin{array}{l}\text { Retinitis pigmentosa } \\
\text { and AMD }\end{array}$ & hiPSCs & hRPE(culture) & $\begin{array}{l}\text { iPSCs differentiate into functional RPEs which } \\
\text { are comparable to fetal and ESC-RPE }\end{array}$ & [85] \\
\hline \multirow[t]{2}{*}{ AMD (clinical) } & Autologous hRPE & Subfoveal space $(\mathrm{h})$ & $\begin{array}{l}\text { Autologous RPE transplantation restores vision } \\
\text { in neovascular AMD }\end{array}$ & [99] \\
\hline & Autologous hRPE & Macula (h) & $\begin{array}{l}\text { Postoperative vision ranged from } 20 / 200 \text { to } 20 / 64 \text {, } \\
\text { with a 2-line increase in three patients. }\end{array}$ & [100] \\
\hline Retinal dystrophy & hESCs & hRPE (r) & $\begin{array}{l}\text { Improvement in visual performance was } 100 \% \\
\text { over untreated controls }\end{array}$ & [101] \\
\hline Glaucoma & hMSCs & Retinal ganglion cells ( $\mathrm{r}$ ) & BM-MSCs deliver neurotrophic factors and neuroprotection & [102] \\
\hline \multirow[t]{3}{*}{ Photoreceptor loss } & $\begin{array}{l}\text { hUTC, hPTC, } \\
\text { hADF and hMSC }\end{array}$ & Photoreceptors (r) & $\begin{array}{l}\text { Umbilical tissue-derived cells gave large areas } \\
\text { of photoreceptor rescue; mesenchymal stem cells } \\
\text { gave only localized rescue }\end{array}$ & [103] \\
\hline & hRPE & $\begin{array}{l}\text { Photoreceptors, rods and } \\
\text { cones (r) }\end{array}$ & $\begin{array}{l}\text { Partial preservation of rod and cone } \\
\text { electroretinogram function }\end{array}$ & [104] \\
\hline & $\mathrm{hRPE} / \mathrm{hSCs}$ & Photoreceptors (r) & hRPE and hSC grafts can survive and rescue photoreceptors & [105] \\
\hline $\begin{array}{l}\text { Macular } \\
\text { degeneration }\end{array}$ & hESC- derived RPE & Photoreceptors $(\mathrm{m} / \mathrm{r})$ & The cells sustained visual function and photoreceptor integrity & [106] \\
\hline
\end{tabular}

Key:

AMD - Age-reltaed macular degeneration

$\mathrm{h}$ - human (may added in before abbreviations)

$\mathrm{m}$ - mouse (may added in before abbreviations)

$\mathrm{r}$ - rat (may add in before abbreviations)

BM-SC - bone marrow stem cells

iPSC — induced pluripotent stem cells

ESC - embryonic stem cells

RPE - retinal pigment epithelium

UTC - umbilical cord tissue-derived cells

PTC - placenta tissue-derived cells

ADF — adult dermal fibroblasts

MSC - mesenchymal stem cells

$\mathrm{SC}$ - stem cells

identified, these cells form a barrier around the lesion, separating damaged tissue from the undamaged [77]. Activated microglia and macrophages produce inflammatory cytokines including IL-1b, IL-6, tumour necrosis factor-alpha (TNF-a), nitric oxide and reactive oxygen species [75]. Inflammatory cytokines have been implicated in signalling migratory pathways for progenitor cells, in the hope of replacing the defective or dead cells [78]. However, excessive cytokines maybe toxic to grafted cells. They have to overcome the pro-inflammatory reaction as well as gliotic barriers, which may hinder its proliferation. Furthermore, microglial cells can serve as antigen-presenting cells, and the immune reaction produced may destroy allografts or xenografts. This poses a major obstacle to the long-term survival of allogeneic RPE or photoreceptor grafts. The eye and brain have been considered to be immune-privileged sites, partly 
because of the existence of the blood-retinal, blood-brain barrier. However, these barriers are often compromised in injured or diseased retina, and blood vessels may become 'leaky' [79]. At present, many transplanted photoreceptor progenitors die following allografts [14]. Graft rejection without immunosuppression may lead to graft rejection [80]. Therefore, immunosuppression may be required at least until the blood-retinal barrier has regained its function after surgery.

\section{Tumorigenicity}

At the moment, no evidences of tumorigenesis have been reported when human ESC-derived retinal progenitor cells were used $[23,56,68,81,82]$. However, there has been one report of tumor formation when neurally selected mouse ESC was transplanted into rodent retina [83]. Therefore, it is vital that a stringent selection process to eliminate any undifferentiated ESC before applying into human trials.

Another potential risk for tumorigenicety is if the cell cultivation period has been prolonged. Djojosubroto [39] reported that chromosomal aberration accumulated rapidly upon prolonged cultivation in ciliary body-derived cells. This maybe potentially tumorigenic; hence, great care must be taken not to prolong the cultivation period.

\section{Future developments}

The use of stem cells in treating retinal degenerative disease has clearly demonstrated great potential for restoring vision. Several issues, however, remain unsolved. A well-defined technique together with a more sustainable and acceptable source of donor cell line have to be sought. At present, stem and progenitor cells transplantation are popular, but in the future, cell-sheet transplantation may be more applicable as it has the advantage of overcoming the problem of integration. However, surgical challenges and the shortage of donor cells are yet to be solved. The continuing search for a sustainable cell source is ongoing. ESC, iPSC, marrow-derived stem cells, umbilical cord-derived cells, and immortalized cell lines are potential candidates. To improve therapeutic effects, an alternative strategy is to combine cell transplantation with gene therapy. A combination of RPE and photoreceptor with anti-angiogenic factors (e.g., anti-vascular endothelial growth factor) may potentially increase cell viability and engraftment.

\section{Conclusions}

In this review, we have presented the current state as well as possible future directions of stem cells therapy for degenerative retinal diseases. While the great potential of stem cell therapy for restoration of visual functions has been clearly demonstrated, several issues are yet unresolved. Appropriate cell sources, targeted cell types for therapy, delivery techniques, and potential risks have to be carefully evaluated before translating into clinical trials. With the development of stem cell biology and technical breakthroughs, clinical translation of RPE transplantation to reconstitute the subretinal anatomy and improve photoreceptor function will hopefully bring hope to the blind.

Acknowledgements This work was supported by NSFC/RGC Joint Research Scheme (N_HKU 716/09 to Q Lian) and Small project funding from the University of Hong Kong (201007176100 to Q Lian).

Open Access This article is distributed under the terms of the Creative Commons Attribution Noncommercial License which permits any noncommercial use, distribution, and reproduction in any medium, provided the original author(s) and source are credited.

\section{References}

1. Sohocki MM, Daiger SP, Bowne SJ, Rodriquez JA, Northrup H, Heckenlively JR, Birch DG, Mintz-Hittner H, Ruiz RS, Lewis RA, Saperstein DA, Sullivan LS (2001) Prevalence of mutations causing retinitis pigmentosa and other inherited retinopathies. Hum Mutat 17:42-51

2. Klein BE (2007) Overview of epidemiologic studies of diabetic retinopathy. Ophthalmic Epidemiol 14:179-183

3. Ah-Fat FG, Sharma MC, Majid MA, McGalliard JN, Wong D (1999) Trends in vitreoretinal surgery at a tertiary referral centre: 1987 to 1996. Br J Ophthal 83:396-398

4. Degenring RF, Cordes A, Schrage NF (2010) Autologous translocation of the retinal pigment epithelium and choroid in the treatment of neovascular age-related macular degeneration. Acta Ophthalmol Mar 19. [Epub ahead of print]

5. Enzmann V, Yolcu E, Kaplan HJ, Ildstad ST (2009) Stem cells as tools in regenerative therapy for retinal degeneration. Arch Ophthalmol 127:563-571

6. Lund RD, Kwan AS, Keegan DJ, Sauvé Y, Coffey PJ, Lawrence JM (2001) Cell transplantation as a treatment for retinal disease. Prog Retin Eye Res 20:415-449

7. Djojosubroto MW, Arsenijevic Y (2008) Retinal stem cells: promising candidates for retina transplantation. Cell Tissue Res 331:347-357

8. MacLaren RE, Taylor JS (1997) Chiasmatic specificity in the regenerating mammalian optic nerve. Exp Neurol 147:279286

9. Chacko DM, Rogers JA, Turner JE, Ahmad I (2000) Survival and differentiation of cultured retinal progenitors transplanted in the subretinal space of the rat. Biochem Biophys Res Commun 268:842-846

10. Yang P, Seiler MJ, Aramant RB, Whittemore SR (2002) Differential lineage restriction of rat retinal progenitor cells in vitro and in vivo. $\mathrm{J}$ Neurosci Res 69:466-476

11. Klassen H, Kiilgaard JF, Zahir T, Ziaeian B, Kirov I, Scherfig E, Warfvinge K, Young MJ (2007) Progenitor cells from the porcine neural retina express photoreceptor markers after transplantation to the subretinal space of allorecipients. Stem Cells 25:1222-1230 
12. Yang P, Seiler MJ, Aramant RB, Whittemore SR (2002) In vitro isolation and expansion of human retinal progenitor cells. Exp Neurol 177:326-331

13. Klassen HJ, Ng TF, Kurimoto Y, Kirov I, Shatos M, Coffey P, Young MJ (2004) Multipotent retinal progenitors express developmental markers, differentiate into retinal neurons, and preserve light-mediated behavior. Invest Ophthalmol Vis Sci 45:4167-4173

14. MacLaren RE, Pearson RA, MacNeil A, Douglas RH, Salt TE, Akimoto M, Swaroop A, Sowden JC, Ali RR (2006) Retinal repair by transplantation of photoreceptor precursors. Nature 444:203-207

15. Aftab U, Jiang C, Tucker B, Kim JY, Klassen H, Miljan E, Sinden J, Young M (2009) Growth kinetics and transplantation of human retinal progenitor cells. Exp Eye Res 89:301-310

16. Osakada F, Ikeda H, Sasai Y, Takahashi M (2009) Stepwise differentiation of pluripotent stem cells into retinal cells. Nat Protoc 4:811-824

17. Osakada F, Jin ZB, Hirami Y, Ikeda H, Danjyo T, Watanabe K, Sasai Y, Takahashi M (2009) In vitro differentiation of retinal cells from human pluripotent stem cells by small-molecule induction. J Cell Sci 122:3169-3179

18. Buchholz DE, Hikita ST, Rowland TJ, Friedrich AM, Hinman CR, Johnson LV, Clegg DO (2009) Derivation of functional retinal pigmented epithelium from induced pluripotent stem cells. Stem Cells 27:2427-2434

19. Idelson M, Alper R, Obolensky A, Ben-Shushan E, Hemo I, Yachimovich-Cohen N, Khaner H, Smith Y, Wiser O, Gropp M, Cohen MA, Even-Ram S, Berman-Zaken Y, Matzrafi L, Rechavi G, Banin E, Reubinoff B (2009) Directed differentiation of human embryonic stem cells into functional retinal pigment epithelium cells. Cell Stem Cell 5:396-408

20. Hirano M, Yamamoto A, Yoshimura N, Tokunaga T, Motohashi T, Ishizaki K, Yoshida H, Okazaki K, Yamazaki H, Hayashi S, Kunisada T (2003) Generation of structures formed by lens and retinal cells differentiating from embryonic stem cells. Dev Dyn 228:664-671

21. Aoki H, Hara A, Niwa M, Motohashi T, Suzuki T, Kunisada T (2008) Transplantation of cells from eye-like structures differentiated from embryonic stem cells in vitro and in vivo regeneration of retinal ganglion-like cells. Graefes Arch Clin Exp Ophthalmol 246:255-265, Epub 2007 Nov 15

22. Vaajasaari H, Ilmarinen T, Juuti-Uusitalo K, Rajala K, Onnela N, Narkilahti S, Suuronen R, Hyttinen J, Uusitalo H, Skottman H (2011) Toward the defined and xeno-free differentiation of functional human pluripotent stem cell-derived retinal pigment epithelial cells. Mol Vis 17:558-575

23. Meyer JS, Katz ML, Maruniak JA, Kirk MD (2006) Embryonic stem cell-derived neural progenitors incorporate into degenerating retina and enhance survival of host photoreceptors. Stem Cells 24:274-283

24. Lian Q, Chow Y, Esteban MA, Pei D, Tse HF (2010) Future perspective of induced pluripotent stem cells for diagnosis, drug screening and treatment of human diseases. Thromb Haemost 104:39-44

25. Carr AJ, Vugler AA, Hikita ST, Lawrence JM, Gias C, Chen LL, Buchholz DE, Ahmado A, Semo M, Smart MJ, Hasan S, da Cruz L, Johnson LV, Clegg DO, Coffey PJ (2009) Protective effects of human iPS-derived retinal pigment epithelium cell transplantation in the retinal dystrophic rat. PLoS One 4:e8152

26. Yu J, Hu K, Smuga-Otto K, Tian S, Stewart R, Slukvin II, Thomson JA (2009) Human induced pluripotent stem cells free of vector and transgene sequences. Science 324:797-801

27. Okita K, Nakagawa M, Hyenjong H, Ichisaka T, Yamanaka S (2008) Generation of mouse induced pluripotent stem cells without viral vectors. Science 322:949-953
28. Kim D, Kim CH, Moon JI, Chung YG, Chang MY, Han BS, Ko S, Yang E, Cha KY, Lanza R, Kim KS (2009) Generation of human induced pluripotent stem cells by direct delivery of reprogramming proteins. Cell Stem Cell 4:472-476

29. Warren L, Manos PD, Ahfeldt T, Loh YH, Li H, Lau F, Ebina W, Mandal PK, Smith ZD, Meissner A, Daley GQ, Brack AS, Collins JJ, Cowan C, Schlaeger TM, Rossi DJ (2010) Highly efficient reprogramming to pluripotency and directed differentiation of human cells with synthetic modified mRNA. Cell Stem Cell 7:618-630

30. Hollyfield JG (1968) Differential addition of cells to the retina in Rana pipiens tadpoles. Dev Biol 18:163-179

31. Feldman JD, Gaze RM (1972) The growth of the retina in Xenopus laevis: an autoradiographic study. II. Retinal growth in compound eyes. J Embryol Exp Morphol 27:381-387

32. Tropepe V, Coles BL, Chiasson BJ, Horsford DJ, Elia AJ, McInnes RR, van der Kooy D (2000) Retinal stem cells in the adult mammalian eye. Science 287:2032-2036

33. Ahmad I, Das AV, James J, Bhattacharya S, Zhao X (2004) Neural stem cells in the mammalian eye: types and regulation. Semin Cell Dev Biol 15:53-62

34. MacNeil A, Pearson RA, MacLaren RE, Smith AJ, Sowden JC, Ali RR (2007) Comparative analysis of progenitor cells isolated from the iris, pars plana, and ciliary body of the adult porcine eye. Stem Cells 25:2430-2438

35. Coles BL, Angénieux B, Inoue T, Del Rio-Tsonis K, Spence JR, McInnes RR, Arsenijevic Y, van der Kooy D (2004) Facile isolation and the characterization of human retinal stem cells. Proc Natl Acad Sci USA 101:15772-15777

36. Asami M, Sun G, Yamaguchi M, Kosaka M (2007) Multipotent cells from mammalian iris pigment epithelium. Dev Biol 304:433-446

37. Gu P, Harwood LJ, Zhang X, Wylie M, Curry WJ, Cogliati T (2007) Isolation of retinal progenitor and stem cells from the porcine eye. Mol Vis 13:1045-1057

38. Xu H, Sta Iglesia DD, Kielczewski JL, Valenta DF, Pease ME, Zack DJ, Quigley HA (2007) Characteristics of progenitor cells derived from adult ciliary body in mouse, rat, and human eyes. Invest Ophthalmol Vis Sci 48:1674-1682

39. Djojosubroto M, Bollotte F, Wirapati P, Radtke F, Stamenkovic I, Arsenijevic Y (2009) Chromosomal number aberrations and transformation in adult mouse retinal stem cells in vitro. Invest Ophthalmol Vis Sci 50:5975-5987

40. Gualdoni S, Baron M, Lakowski J, Decembrini S, Smith AJ, Pearson RA, Ali RR, Sowden JC (2010) Adult ciliary epithelial cells, previously identified as retinal stem cells with potential for retinal repair, fail to differentiate into new rod photoreceptors. Stem Cells 28:1048-1059

41. Guo Y, Saloupis P, Shaw SJ, Rickman DW (2003) Engraftment of adult neural progenitor cells transplanted to rat retina injured by transient ischemia. Invest Ophthalmol Vis Sci 44:3194-3201

42. Das AV, Mallya KB, Zhao X, Ahmad F, Bhattacharya S, Thoreson WB, Hegde GV, Ahmad I (2006) Neural stem cell properties of Müller glia in the mammalian retina: regulation by Notch and Wnt signaling. Dev Biol 299:283-302

43. Harris JR, Fisher R, Jorgensen M, Kaushal S, Scott EW (2009) CD133 progenitor cells from the bone marrow contribute to retinal pigment epithelium repair. Stem Cells 27:457-466

44. Zwart I, Hill AJ, Al-Allaf F, Shah M, Girdlestone J, Sanusi AB, Mehmet H, Navarrete R, Navarrete C, Jen LS (2009) Umbilical cord blood mesenchymal stromal cells are neuroprotective and promote regeneration in a rat optic tract model. Exp Neurol 216:439-448

45. Takahashi M, Palmer TD, Takahashi J, Gage FH (1998) Widespread integration and survival of adult-derived neural 
progenitor cells in the developing optic retina. Mol Cell Neurosci 12:340-348

46. Nishida A, Takahashi M, Tanihara H, Nakano I, Takahashi JB, Mizoguchi A, Ide C, Honda Y (2000) Incorporation and differentiation of hippocampus-derived neural stem cells transplanted in injured adult rat retina. Invest Ophthalmol Vis Sci 41:4268-4274

47. Tian B, Li XX, Shen L, Zhao M, Yu WZ (2010) Auto-mobilized adult hematopoietic stem cells advance neovasculature in diabetic retinopathy of mice. Chin Med J (Engl) 123:2265-2268

48. Kicic A, Shen WY, Wilson AS, Constable IJ, Robertson T, Rakoczy PE (2003) Differentiation of marrow stromal cells into photoreceptors in the rat eye. J Neurosci 23:7742-7749

49. Lian Q, Lye E, Suan Yeo K, Khia Way Tan E, Salto-Tellez M, Liu TM, Palanisamy N, El Oakley RM, Lee EH, Lim B, Lim SK (2007) Derivation of clinically compliant MSCs from CD105+, CD24-differentiated human ESCs. Stem Cells 25:425-436

50. Lian Q, Zhang Y, Zhang J, Zhang HK, Wu X, Zhang Y, Lam FF, Kang S, Xia JC, Lai WH, Au KW, Chow YY, Siu CW, Lee CN, Tse HF (2010) Functional mesenchymal stem cells derived from human induced pluripotent stem cells attenuate limb ischemia in mice. Circulation 121:1113-1123

51. Levkovitch-Verbin H, Sadan O, Vander S, Rosner M, Barhum Y, Melamed E, Offen D, Melamed S (2010) Intravitreal injections of neurotrophic factors secreting mesenchymal stem cells are neuroprotective in rat eyes following optic nerve transection. Invest Ophthalmol Vis Sci 51:6394-6400

52. Liu Y, Gao L, Zuba-Surma EK, Peng X, Kucia M, Ratajczak MZ, Wang W, Enzmann V, Kaplan HJ, Dean DC (2009) Identification of small Sca-1(+), Lin(-), CD45(-) multipotential cells in the neonatal murine retina. Exp Hematol 37:1096-1107

53. Li Y, Atmaca-Sonmez P, Schanie CL, Ildstad ST, Kaplan HJ, Enzmann V (2007) Endogenous bone marrow derived cells express retinal pigment epithelium cell markers and migrate to focal areas of RPE damage. Invest Ophthalmol Vis Sci 48(9):43214327

54. Li LX, Turner JE (1988) Transplantation of retinal pigment epithelial cells to immature and adult rat hosts: Short- and long-term survival characteristics. Exp Eye Res 47:771-785

55. Lopez R, Gouras P, Kjeldbye H, Sullivan B, Reppucci V, Brittis M, Wapner F, Goluboff E (1989) Transplanted retinal pigment epithelium modifies the retinal degeneration in the RCS rat. Invest Ophthalmol Vis Sci 30:586-588

56. Lund RD, Wang S, Klimanskaya I, Holmes T, Ramos-Kelsey R, Lu B, Girman S, Bischoff N, Sauvé Y, Lanza R (2006) Human embryonic stem cell-derived cells rescue visual function in dystrophic RCS rats. Cloning Stem Cells 8:189-199

57. Wang S, Lu B, Wood P, Lund RD (2005) Grafting of ARPE-19 and Schwann cells to the subretinal space in RCS rats. Invest Ophthalmol Vis Sci 46:2552-2560

58. Peyman GA, Blinder KJ, Paris CL, Alturki W, Nelson NC Jr, Desai U (1991) A technique for retinal pigment epithelium transplantation for age-related macular degeneration secondary to extensive subfoveal scarring. Ophthalmic Surg 22:102-108

59. da Cruz L, Chen FK, Ahmado A, Greenwood J, Coffey P (2007) RPE transplantation and its role in retinal disease. Prog Retin Eye Res 26:598-635

60. van Meurs JC, Van Den Biesen PR (2003) Autologous retinal pigment epithelium and choroid translocation in patients with exudative age-related macular degeneration: Short-term followup. Am J Ophthalmol 136:688-695

61. Chen FK, Uppal GS, MacLaren RE, Coffey PJ, Rubin GS, Tufail A, Aylward GW, Da Cruz L (2009) Long-term visual and microperimetry outcomes following autologous retinal pigment epithelium choroid graft for neovascular age-related macular degeneration. Clin Experiment Ophthalmol 37:275-285
62. Valtink M, Engelmann K, Krüger R, Schellhorn ML, Löliger C, Püschel K, Richard G (1999) Structure of a cell bank for transplantation of HLA-typed, cryopreserved human adult retinal pigment epithelial cells. Ophthalmologe 96:648-652

63. Kwan AS, Wang S, Lund RD (1999) Photoreceptor layer reconstruction in a rodent model of retinal degeneration. Exp Neurol 159:21-33

64. Aramant RB, Seiler MJ (2004) Progress in retinal sheet transplantation. Prog Retin Eye Res 23:475-494

65. Léveillard T, Mohand-Saïd S, Sahel JA (2007) Retinal repair by transplantation of photoreceptor precursors. Med Sci (Paris) 23:240-242

66. Coles BL, Angénieux B, Inoue T, Del Rio-Tsonis K, Spence JR, McInnes RR, Arsenijevic Y, van der Kooy D (2004) Facile isolation and the characterization of human retinal stem cells. Proc Natl Acad Sci USA 101:15772-15777

67. Bull ND, Limb GA, Martin KR (2008) Human Muller stem cell (MIO-M1) transplantation in a rat model of glaucoma: survival, differentiation, and integration. Invest Ophthalmol Vis Sci 49:3449-3456

68. Banin E, Obolensky A, Idelson M, Hemo I, Reinhardtz E, Pikarsky E, Ben-Hur T, Reubinoff B (2006) Retinal incorporation and differentiation of neural precursors derived from human embryonic stem cells. Stem Cells 24:246-257

69. Sakaguchi DS, Van Hoffelen SJ, Theusch E, Parker E, Orasky J, Harper MM, Benediktsson A, Young MJ (2004) Transplantation of neural progenitor cells into the developing retina of the Brazilian opossum: An in vivo system for studying stem/progenitor cell plasticity. Dev Neurosci 26:336-345

70. Tomita M, Lavik E, Klassen H, Zahir T, Langer R, Young MJ (2005) Biodegradable polymer composite grafts promote the survival and differentiation of retinal progenitor cells. Stem Cells 23:1579-1588

71. Kurz T, Karlsson M, Brunk UT, Nilsson SE, Frennesson C (2009) ARPE-19 retinal pigment epithelial cells are highly resistant to oxidative stress and exercise strict control over their lysosomal redox-active iron. Autophagy 5:494-501

72. Klimanskaya I, Hipp J, Rezai KA, West M, Atala A, Lanza R (2004) Derivation and comparative assessment of retinal pigment epithelium from human embryonic stem cells using transcriptomics. Cloning Stem Cells 6:217-245

73. Seiler MJ, Aramant RB (2005) Transplantation of neuroblastic progenitor cells as a sheet preserves and restores retinal function. Semin Ophthalmol 20:31-42

74. Suzuki T, Mandai M, Akimoto M, Yoshimura N, Takahashi M (2006) The simultaneous treatment of MMP-2 stimulants in retinal transplantation enhances grafted cell migration into the host retina. Stem Cells 24:2406-2411

75. Langmann T (2007) Microglia activation in retinal degeneration. J Leukoc Biol 81:1345-51

76. Zhang C, Shen JK, Lam TT, Zeng HY, Chiang SK, Yang F, Tso MO (2005) Activation of microglia and chemokines in lightinduced retinal degeneration. Mol Vis 11:887-895

77. Nimmerjahn A, Kirchhoff F, Helmchen F (2005) Resting microglial cells are highly dynamic surveillants of brain parenchyma in vivo. Science 308:1314-1318

78. Belmadani A, Tran PB, Ren D, Miller RJ (2006) Chemokines regulate the migration of neural progenitors to sites of neuroinflammation. J Neurosci 26:3182-3191

79. Hernandez MR (2000) The optic nerve head in glaucoma: role of astrocytes in tissue remodeling. Prog Retin Eye Res 19:297-321

80. Algvere PV, Gouras P, Dafgård Kopp E (1999) Long-term outcome of RPE allografts in non-immunosuppressed patients with AMD. Eur J Ophthalmol 9:217-230 
81. Meyer JS, Katz ML, Maruniak JA, Kirk MD (2004) Neural differentiation of mouse embryonic stem cells in vitro and after transplantation into eyes of mutant mice with rapid retinal degeneration. Brain Res 1014:131-144

82. Coffey PJ, Girman S, Wang SM, Hetherington L, Keegan DJ, Adamson P, Greenwood J, Lund RD (2002) Long-term preservation of cortically dependent visual function in RCS rats by transplantation. Nat Neurosci 5:53-56

83. Arnhold S, Klein H, Semkova I, Addicks K, Schraermeyer U (2004) Neurally selected embryonic stem cells induce tumor formation after long-term survival following engraftment into the subretinal space. Invest Ophthalmol Vis Sci 45:4251-4255

84. Thummel R, Enright JM, Kassen SC, Montgomery JE, Bailey TJ (2010) Hyde DR (2010) Pax6a and Pax6b are required at different points in neuronal progenitor cell proliferation during zebrafish photoreceptor regeneration. Exp Eye Res 90(5):572582

85. Buchholz DE, Hikita ST, Rowland TJ, Friedrich AM, Hinman CR, Johnson LV, Clegg DO (2009) Derivation of functional retinal pigmented epithelium from induced pluripotent stem cells. Stem Cells 27:2427-2434

86. Lee E, Maclaren RE (2011) Sources of retinal pigment epithelium (RPE) for replacement therapy. $\mathrm{Br} \mathrm{J}$ Ophthalmol 95:445-449, Epub 2010 Jul 3

87. Idelson M, Alper R, Obolensky A, Ben-Shushan E, Hemo I, Yachimovich-Cohen N, Khaner H, Smith Y, Wiser O, Gropp M, Cohen MA, Even-Ram S, Berman-Zaken Y, Matzrafi L, Rechavi G, Banin E, Reubinoff B (2009) Directed differentiation of human embryonic stem cells into functional retinal pigment epithelium cells. Cell Stem Cell 5(4):396-408

88. Vaajasaari H, Ilmarinen T, Juuti-Uusitalo K, Rajala K, Onnela N, Narkilahti S, Suuronen R, Hyttinen J, Uusitalo H, Skottman H (2011) Toward the defined and xeno-free differentiation of functional human pluripotent stem cell-derived retinal pigment epithelial cells. Mol Vis 17:558-575

89. Zwart I, Hill AJ, Al-Allaf F, Shah M, Girdlestone J, Sanusi AB, Mehmet H, Navarrete R, Navarrete C, Jen LS (2009) Umbilical cord blood mesenchymal stromal cells are neuroprotective and promote regeneration in a rat optic tract model. Exp Neurol 216:439-448

90. Nickerson PE, Emsley JG, Myers T, Clarke DB (2007) Proliferation and expression of progenitor and mature retinal phenotypes in the adult mammalian ciliary body after retinal ganglion cell injury. Invest Ophthalmol Vis Sci 48:5266-5275

91. Haruta M, Kosaka M, Kanegae Y, Saito I, Inoue T, Kageyama R, Nishida A, Honda Y, Takahashi M (2001) Induction of photoreceptor-specific phenotypes in adult mammalian iris tissue. Nat Neurosci 4:1163-1164

92. Otani A, Otani A, Dorrell MI, Kinder K, Moreno SK, Nusinowitz S, Banin E, Heckenlively J, Friedlander M et al (2004) Rescue of retinal degeneration by intravitreally injected adult bone marrow-derived lineage-negative hematopoietic stem cells. J Clin Invest 114:765-774

93. Lu B, Wang S, Girman S, McGill T, Ragaglia V, Lund R (2010) Human adult bone marrow-derived somatic cells rescue vision in a rodent model of retinal degeneration. Exp Eye Res 91:449455, Epub 2010 Jul 13

94. Castanheira P, Torquetti L, Nehemy MB, Goes AM (2008) Retinal incorporation and differentiation of mesenchymal stem cells intravitreally injected in the injured retina of rats. Arq Bras Oftalmol 71:644-650

95. Yue F, Johkura K, Shirasawa S, Yokoyama T, Inoue Y, Tomotsune D, Sasaki K (2010) Differentiation of primate ES cells into retinal cells induced by ES cell-derived pigmented cells. Biochem Biophys Res Commun 394:877-883, Epub 2010 Mar 4

96. Chaudhry GR, Fecek C, Lai MM, Wu WC, Chang M, Vasquez A, Pasierb M, Trese MT (2009) Fate of embryonic stem cell derivatives implanted into the vitreous of a slow retinal degenerative mouse model. Stem Cells Dev 18:247-258

97. West EL, Pearson RA, Barker SE, Luhmann UF, Maclaren RE, Barber AC, Duran Y, Smith AJ, Sowden JC, Ali RR (2010) Longterm survival of photoreceptors transplanted into the adult murine neural retina requires immune modulation. Stem cells 28:1997-2007

98. Sasahara M, Otani A, Oishi A, Kojima H, Yodoi Y, Kameda T, Nakamura H, Yoshimura N (2008) Activation of bone marrowderived microglia promotes photoreceptor survival in inherited retinal degeneration. Am J Pathol 172:1693-1703, Epub 2008 May 15

99. MacLaren RE, Uppal GS, Balaggan KS, Tufail A, Munro PM, Milliken AB, Ali RR, Rubin GS, Aylward GW, da Cruz L (2007) Autologous transplantation of the retinal pigment epithelium and choroid in the treatment of neovascular age-related macular degeneration. Ophthalmology 114:561-570

100. van Meurs JC, Van Den Biesen PR (2003) Autologous retinal pigment epithelium and choroid translocation in patients with exudative age-related macular degeneration: short-term follow-up. Am J Ophthalmol 136:688-695

101. Lund RD, Wang S, Klimanskaya I, Holmes T, Ramos-Kelsey R, Lu B, Girman S, Bischoff N, Sauvé Y, Lanza R (2006) Human embryonic stem cell-derived cells rescue visual function in dystrophic RCS rats. Cloning Stem Cells 8:189-199

102. Levkovitch-Verbin H, Sadan O, Vander S, Rosner M, Barhum Y, Melamed E, Offen D, Melamed S (2010) Intravitreal injections of neurotrophic factors secreting mesenchymal stem cells are neuroprotective in rat eyes following optic nerve transection. Invest Ophthalmol Vis Sci 51:6394-6400

103. Lund RD, Wang S, Lu B, Girman S, Holmes T, Sauvé Y, Messina DJ, Harris IR, Kihm AJ, Harmon AM, Chin FY, Gosiewska A, Mistry SK (2007) Cells isolated from umbilical cord tissue rescue photoreceptors and visual functions in a rodent model of retinal disease. Stem Cells 25:602-11

104. Sauvé Y, Pinilla I, Lund RD (2006) Partial preservation of rod and cone ERG function following subretinal injection of ARPE-19 cells in RCS rats. Vision res 46:1459-1472

105. Wang S, Lu B, Wood P, Lund RD (2005) Grafting of ARPE-19 and Schwann cells to the subretinal space in RCS rats. Invest Ophthalmol Vis Sci 46:2552-2560

106. Lu B, Malcuit C, Wang S, Girman S, Francis P, Lemieux L, Lanza R, Lund R (2009) Long-term safety and function of RPE from human embryonic stem cells in preclinical models of macular degeneration. Stem Cells 27:2126-2135 